\title{
Assessing the Breeding Success of the Western Grebe (Aechmophorus occidentalis) After 40 Years of Environmental Changes at Delta Marsh, Manitoba
}

Author(s): Nicholas La Porte , Nicola Koper and Lionel Leston

Source: Waterbirds, 37(1):30-42. 2014.

Published By: The Waterbird Society

DOI: http://dx.doi.org/10.1675/063.037.0106

URL: http://www.bioone.org/doi/full/10.1675/063.037.0106

BioOne (www.bioone.org) is a nonprofit, online aggregation of core research in the biological, ecological, and environmental sciences. BioOne provides a sustainable online platform for over 170 journals and books published by nonprofit societies, associations, museums, institutions, and presses.

Your use of this PDF, the BioOne Web site, and all posted and associated content indicates your acceptance of BioOne's Terms of Use, available at www.bioone.org/ page/terms_of_use.

Usage of BioOne content is strictly limited to personal, educational, and noncommercial use. Commercial inquiries or rights and permissions requests should be directed to the individual publisher as copyright holder. 


\title{
Assessing the Breeding Success of the Western Grebe (Aechmophorus occidentalis) after 40 Years of Environmental Changes at Delta Marsh, Manitoba
}

\author{
Nicholas La Porte, Nicola Koper ${ }^{*}$ and Lionel Leston \\ Natural Resources Institute, University of Manitoba, Winnipeg, Manitoba, Canada \\ "Corresponding author; E-mail: Nicola.Koper@umanitoba.ca
}

\begin{abstract}
Since the 1970s, artificially stabilized water levels, increased presence of common carp (Cyprinus carpio) and invasion by a cattail hybrid (Typha $\times$ glauca) have changed the nesting environment for Western Grebes (Aechmophorus occidentalis) at Delta Marsh, Manitoba. To evaluate the impact of these changes, nest survival rates, causes of nest mortality, wind conditions, locations of nests and vegetation structure at nests in 2009-2010, and chick-adult ratios were compared to similar data for Western Grebes at Delta Marsh from 1973-1974. Apparent nest survival rates were lower in 2009-2010 than 1973-1974, and between low-water years $(1973,2010)$ and high-water years $(1974,2009)$. Lower apparent nest survival rates in 2009-2010 (49\% in 2009 and $43 \%$ in 2010, compared to $46 \%$ in 1973 and $84 \%$ in 1974), and chick-adult ratios (0.55 in 1973 and 0.88 in 1974, compared to 0.55 in 2009 and 0.39 in 2010) were attributed to increases in destruction of nests primarily by wave action and secondarily by common carp, which were not observed destroying Western Grebe nests in 1973-1974. The replacement of native bulrushes by cattails in Western Grebe nesting habitat may have caused the observed increase in proximity to openwater edge, and this proximity may have increased destruction of nests by waves. Restoring stands of emergent bulrush by varying marsh water levels and reducing carp in the marsh might improve nest survival of Western Grebes. Received 19 June 2013, accepted 20 September 2013.
\end{abstract}

Key words.-Aechmophorus occidentalis, Cyprinus carpio, nest survivorship, Typha glauca, Western Grebe.

Waterbirds 37(1): 30-42, 2014

The Western Grebe (Aechmophorus occidentalis) is a large colonial, piscivorous waterbird of high conservation concern in the Northern Prairie and Parkland Region of western North America (Beyersbergen et al. 2004). One of its historic breeding areas in Manitoba is Delta Marsh, located on the south shore of Lake Manitoba (Nuechterlein 1975, 2003). Delta Marsh is a wetland of international importance under the Ramsar Convention (Ramsar Convention 2009) and a Provincial Heritage Marsh, and was designated as a nationally Important Bird Area in 1991 (Goldsborough and Wrubleski 2001). Thus, conservation of Delta Marsh and its wildlife is extremely important in a provincial, national and global context.

Delta Marsh was a regionally important habitat for Western Grebes, with reported apparent nest survival rates of $46 \%$ in 1973 and $84 \%$ in 1974, and chick-adult ratios of 0.55 in 1973 and 0.88 in 1974 (Nuechterlein 1975). However, it is not known if this location is as productive currently. Although ongoing habitat changes at Delta Marsh over the last 3 decades may have affected nest survival of Western Grebes adversely, there have been few recent attempts to monitor their populations (Koonz and Rakowski 1985). Artificial stabilization of water levels in the marsh and lake by damming and water diversion has resulted in significant hydrological changes to the marsh and may be enhancing the spread of an exotic hybrid cattail (Typha x glauca) (Keddy and Reznicek 1986). Hybrid cattails are replacing native shoreline vegetation, particularly hardstem bulrush (Scirpus lacustris spp. glaucus), an important component of Western Grebe nesting habitat. Western Grebes build semifloating nests by collecting bits of emergent vegetation like cattail and bulrush off the marsh bottom, cutting vegetation with their beaks from living plants, and situating nests off or on top of emergent plants growing out of the marsh bottom (Kuehn and White 1999; Shay et al. 1999; Goldsborough and Wrubleski 2001). Introduced common carp (Cyprinus carpio; hereafter carp) may also destroy nests by thrashing during spawning, degrade nesting habitat and reduce nest survival of Western Grebes (Goldsborough and Wrubleski 2001). In light of these ecological changes in Delta Marsh, we felt it was important to re-evaluate nesting ecology of Western Grebes there. 
Within Delta Marsh and other coastal marshes of southern Lake Manitoba, the long-term stabilization of water levels by dams and water diversions may have impacted the composition and structure of emergent vegetation, which is used as a nesting substrate by Western Grebes and several other waterbird species (McNicholl 2003a; Nuechterlein 2003; Nuechterlein et al. 2003). Prior to construction of the Fairford River Dam in 1961, water levels fluctuated by more than $2.2 \mathrm{~m}$ across and within years (Shay et al. 1999). Since then, dams and water diversions have regulated the water levels of Lake Manitoba and therefore Delta Marsh, at a mean target of $247.6 \mathrm{~m}$ above sea level, so that yearly water levels fluctuate by no more than $0.6 \mathrm{~m}$ (Fig. 1; Squires and van der Valk 1992; Shay et al. 1999). Although in the short term this might reduce nest losses that are common in low-water years (Nero 1958; Nuechterlein 1975), long-term fluctuations in water levels benefit wetland conservation and regeneration. High water levels open up areas of dense cattails, because in deep water cattails either die of anoxic conditions, or produce fewer, longer shoots than they do in shallow water (Squires and van der Valk 1992); low water levels allow for the replacement of monoculture cattail stands with other species of emergent vegetation that occur at shallower depths (Squires and van der Valk 1992). The spread of Typha $\mathrm{x}$ glauca has been exacerbated by reduced water level variability (Keddy and Reznicek 1986). Typha $\times$ glauca has few herbivores and its dead stems are slow to decompose; the resulting accumulation of litter reduces soil light and temperature levels, reducing the growth of competing native species while not affecting Typha $\times$ glauca live stems (Larkin et al. 2012). Therefore, reduced wetland water level variation reduces diversity of emergent vegetation (Keddy and Reznicek 1986).

Changes in the hydrology and vegetation structure of Delta Marsh may have not only reduced the amount of preferred nesting habitat of Western Grebes, but also the survival of their nests. Previous research at Delta Marsh suggested that nest survival was influenced by wave exposure, water depth and emergent vegetation stem density (Nuechterlein 1975). Wave action can disintegrate the nests of accumulated floating aquatic vegetation (Lindvall and Low 1982). However, emergent and underwater stems reduce the amount of energy waves can carry to nests by bending with wave action, thus absorbing energy and increasing the frictional forces to attenuate waves (Denny 1988; Hall et al. 1998). Beds of bulrush have greater underwater surface area and underwater stem densities than cattails, and thus greater frictional forces to attenuate wave energy than hybrid cattail (Denny 1988; Hall et al. 1998). Although cattail root systems are dense, the clumped growth of cattails deflects waves more than they attenuate wave energy (Denny 1988; Hall et al. 1998). Further, a lack of bulrush or flooded cattail stands due to water level stabilization may restrict Western Grebe nests to the periphery

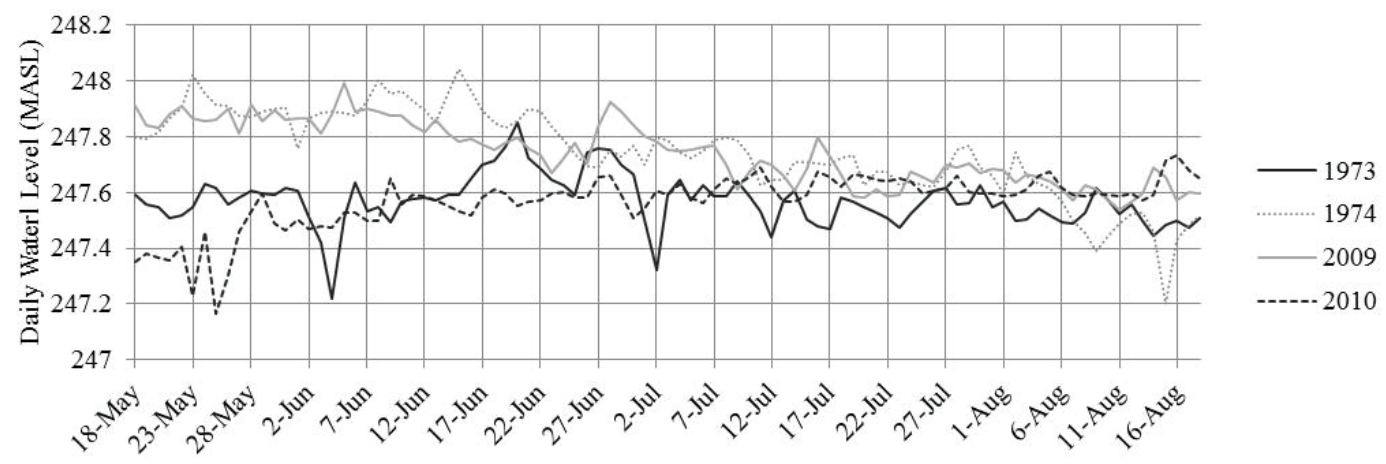

Figure 1. Daily water levels in meters above sea level (MASL) at Delta Marsh, Manitoba, Canada, for 1973, 1974, 2009, and 2010 (Westbourne gauging station 05LL012, Environment Canada). 
of dense cattail stands. These nests are more exposed to waves, reducing the likelihood of nest survival (Nuechterlein 1975; Lindvall and Low 1982; Denny 1988), and may also be more exposed to predators. Therefore, changes in the quantity and quality of vegetation structure at Delta Marsh may affect Western Grebe nest survival and nest survival of other species nesting in emergent vegetation there (McNicholl 1982; Nuechterlein 2003).

Carp may also reduce both the availability of suitable nest vegetation and nest survival of Western Grebes. Since their invasion of Delta Marsh in 1948 (Evelsizer and Turner 2006), carp have become the predominant fish species in terms of biomass (Goldsborough and Wrubleski 2001). By uprooting marsh vegetation during foraging and spawning (McNicholl 1982; Crivelli 1983; Breukelaar et al. 1994; Chow-Fraser 1998), carp may incidentally destroy Western Grebe nests and other floating nests. Grazing by carp might also destroy nesting habitat by reducing submerged macrophyte species diversity and cover (Havens 1991; Breukelaar et al. 1994; Hnatiuk 2006; Miller and Crowl 2006) or by smashing eggs during spawning (McNicholl 1982). To determine if and how changes to the nesting environment in Delta Marsh between 1973-1974 and 2009-2010 affected nest survival of Western Grebes, we compared nest survival rates, causes of nest loss, chick-adult ratios, nest locations, vegetation structure at nests, and wind speeds between surveys conducted in 1973-1974 (Nuechterlein 1975) and surveys we conducted in 2009-2010. We also compared Western Grebe nesting ecology between years with low water levels (June 1973: mean of $247.6 \mathrm{~m}$ above sea level (MASL); June 2010: 247.5 MASL), and years with high water levels (1974 = 2009: 247.8 MASL) (Fig. 1; Environment Canada 2011).

\section{Methods}

\section{Study Area}

Delta Marsh $\left(50^{\circ} 11^{\prime} 55^{\prime \prime} \mathrm{N}, 98^{\circ} 12^{\prime} 17^{\prime \prime} \mathrm{W}\right)$ is approximately 18,500 ha and composed of a series of channels connecting a network of shallow (0.3-2.0 m deep) open- water bays. A narrow, forested beach ridge separates the marsh from Lake Manitoba. Water exchange between Lake Manitoba and Delta Marsh takes place through two channels in the East Unit of the marsh that cross the ridge. The Delta Marsh is described in more detail by Hochbaum (1971), with numerous biological studies conducted at the Delta Waterfowl and Wetlands Research Station since the 1930s (McNicholl 2003b).

The shorelines of the bays are fringed by stands of cattail (Typha spp.) and bulrush (Scirpus spp., Schoenoplectus spp.), sometimes bounded by stands of Phragmites (Shay et al. 1999). Phragmites australis was the dominant emergent plant species in terms of cover at Delta Marsh before installation of the Fairford River Dam in 1961. Since then, Typha $\times$ glauca has become the dominant species at Delta Marsh, although P. australis is still abundant along eroded southern shorelines and at higher elevations (Shay et al. 1999). Nest substrates of Western Grebes are constructed from vegetation such as floating stems of emergent plants rooted in the marsh bottom and pieces of vegetation either collected from the marsh bottom or cut from living plants (Nuechterlein 2003). Nesting islands of Western Grebes consisted primarily of emergent bulrushes (Scirpus validus) (1973: $98 \%$ bulrush, $2 \%$ cattail; $1974: 30 \%$ bulrush, $11 \%$ cattail, $59 \%$ P. australis). Nesting islands had all three species of plants growing in distinct contiguous patches in the 1970s (Nuechterlein 1975). Bulrushes declined while Typha $\times$ glauca increased in a section of Delta Marsh where water levels were stabilized (flooded for 5 years) after a draw-down period in the 1990s (Seabloom et al. 2001). From 1964-1997, cattail cover (ha) in the isolated Center Marsh increased by $819 \%$, bulrush cover declined by $97 \%$, and open water area declined by 19\% (Goldsborough and Wrubleski 2001).

\section{Nest and Colony Characteristics}

We located and monitored Western Grebe nests at Delta Marsh to compare our nest data in 2009-2010 to nest data collected from 1973-1974 (Nuechterlein 1975). This began with a preliminary survey in early May (2009-2010) from an airboat to determine the general location of Western Grebe colonies. Since Western Grebe aggregations are visually and audibly conspicuous, we were confident that we located all colonies during the study. Following the preliminary survey, we used kayaks to travel to and identify individual nest sites within colonies. We classified nests as initiated only after eggs were laid (Nuechterlein 1975).

We used aerial photographs to map locations of individual nests in the largest colonies to allow us to assess effects of nest distance to open-water edge, wave exposure and other factors on nest survival. After hatching in the largest colonies ended, and the colonies were uninhabited, we tied white plastic bags to emergent vegetation above each remaining nest to provide visible markers on aerial photographs. The morning after, we took photos with a Panasonic DMC-T25 10.7 MP digital camera from a small fixed-wing aircraft $(<200 \mathrm{kmph}$, $300 \mathrm{~m}$ altitude). After the flight, we matched nest identification numbers to nest sites on the aerial pho- 
tograph, and then we removed plastic bags from the colonies. Only those nests remaining after hatching was complete were included on the maps. Evidence of some nests was absent by then, so habitat variables could not be quantified for those nests. Starting in 2010, we measured water depth $(\mathrm{cm})$ below nests.

We geo-referenced aerial photos to 2009 satellite imagery of Delta Marsh (Ducks Unlimited, Canada, unpubl. data) using ArcGIS (Environmental Systems Research Institute 2002). Due to difficulties in photographing the entire length of one of the nesting islands (Gibby's Island), we mapped only the largest portion (southern part) in ArcGIS; we were able to geo-reference the entirety of the other nesting island (Blackfox North Island).

Using the digitized colony maps, we measured the shortest distance from each marked nest to the openwater edge of the nesting island, as well as the fetch of open water (distance of each nest to closest wave break or shoreline) along the same bearing as indices of wave exposure. Because the predominant wind directions are from the northwest in spring and summer at Delta Marsh (Environment Canada 2012), we classified nests as either on the windward (northwest) or the leeward (southeast) side of nesting islands by bisecting the islands, using a straight line from $225^{\circ}$ southwest to $45^{\circ}$ northeast across the center of each nesting island.

Weather

To determine if changes in apparent nest survival between 1973-1974 and 2009-2010 might be explained by differences in wind intensity, we calculated average maximum daily wind speeds from 18 May to 31 July for each year. Because wind speeds on days with maximum daily wind speeds below $31 \mathrm{kmph}$ were not available (Environment Canada 2012), we assigned these days the value of $16 \mathrm{kmph}$, i.e. (31-0 kmph)/2, for calculating average maximum daily wind speed; thus, the precise mean wind speeds for all years are not known, but we could approximate relative differences among years. We used Welch's $t$-tests to compare average maximum daily wind speed between years, and $\chi^{2}$-tests to compare frequencies of high wind events among years. We omitted rare counts of high wind events greater than 70 kmph from the $\chi^{2}$-test to meet the minimum criterion and assumptions of the test (Quinn and Keough 2002).

\section{Nest Survival}

We revisited colonies to record the number, status and distribution of nests, at intervals of 7 days or more, on sunny, warm, calm days to minimize disturbance to nests (Nuechterlein 1975). To facilitate relocation, we numbered and marked nest sites with very small pieces of flagging tape, which did not increase depredation rates of nests (Greenwood and Sargeant 1995). During each visit, we recorded clutch size and numbered each egg with a black marker (Boonstra 2006). We determined the age of individual eggs with the flotation method, then immediately returned eggs to their nests (Nuechterlein 1975). We confidently assessed nests as failed if nests were empty at a stage prior to when they could have conceivably hatched. Nests with more than six eggs, which is the maximum successful clutch size for Western Grebes (Storer and Nuechterlein 1992), were always cold; we classified these nests as abandoned, due to or concurrent with parasitism by conspecifics.

We only used outcomes of the initial nest (first laid clutch in each known nest) to calculate nest survival rates per colony (Nuechterlein 1975), because Western Grebes persistently re-nest (Storer and Nuechterlein 1992; Van Damme 2004, 2006) and will either reuse successful nests or build on top of abandoned or damaged nests (Van Damme 2004, 2006). Nesting losses were based on the negative outcomes of each clutch, as new clutches were initiated in some nests following completion of previous clutches. It is not known if the same or a second breeding pair reinitiated a particular nest. For these reasons, the total number of analyzed nests was fewer than the actual number of nesting losses found, which was fewer than the total number of nesting losses in the largest colonies. In some cases, multiple clutches laid sequentially in a single nest were destroyed by predators and/or wave action.

\section{Chick-Adult Ratios}

Following the peak of hatching in early August, we conducted brood surveys in all major bays of Delta Marsh and along the southern shore of Lake Manitoba. Brood surveys by Nuechterlein (1975) were limited to the marsh, as water control structures blocked access by Western Grebes to the lake. However, to ensure that we surveyed the Western Grebe population thoroughly, surveys in 2009-2010 included southern Lake Manitoba as the formerly blocked channels were now open, providing Western Grebes access to the lake. Though unlikely, Western Grebe populations within Delta Marsh and along Lake Manitoba's southern shore may have received minimal additional inputs of Western Grebe broods from other populations.

To be consistent with Nuechterlein's (1975) methods, we conducted brood surveys on the first very calm days in the first week of August from an hour after sunrise to the early afternoon. Chicks were on average 3040 days old by then, in both studies. We spaced observation points $2 \mathrm{~km}$ apart along $22 \mathrm{~km}$ of Lake Manitoba's shore adjacent to Delta Marsh. We recorded numbers of adults and chicks along with chick age class (Nuechterlein 1975), but could not count back-brooded chicks with confidence; thus we excluded those chicks when calculating ratios for consistency with the earlier surveys (Nuechterlein 1975). Our methods assume that broods were equally detectable in the 1970 s as in the 2000 s; this assumption is reasonable because broods occupy openwater habitat where they are easily detected and do not spend much time in the emergent vegetation where exposure to mammalian predators is probably high (Lokemoen and Woodward 1992). However, we recognize that we have no way to quantify whether detectability of broods was similar between 1973-1974 and 2009-2010.

\section{Effects of Habitat Structure on Nest Survival}

To facilitate comparisons with available 1970s data, which were only from large colonies, and to control for 
the fact that nest survival might vary with colony size, we determined causes of individual nest failures for two large colonies in 2009 and the largest 2010 colony. We did not include the largest colony in 2009 (Sioux Point Lake) in comparisons with the 1970s, because we located nests in this colony late in the season; thus, this colony may have sustained nesting losses before observation began. Data from 1973 and 1974 were not available separately; data from four major colonies (1973: Division Bay and Cook's Creek; 1974: Waterhen Arm and Division Bay South) were combined by Nuechterlein (1975). Nests were generally surrounded by other Western Grebe nests; however, Nuechterlein (1975) did not indicate whether other species like Forster's Terns (Sterna forsteri) co-occurred with Western Grebes. Forster's Terns will depredate eggs, and their nests did cooccur with Western Grebe nests in 2009 and 2010.

To test if rates of nesting losses differed between 1973-1974 and 2009-2010, we combined nesting losses from the 2009 and 2010 data, then collapsed probable causes of nesting losses into a dichotomous variable $\chi^{2}-$ test of pooled depredation-caused losses and storm-related losses to meet the minimum sample-size-per-cell criterion of a $\chi^{2}$-test. To be consistent with Nuechterlein (1975), we used initial nests for this comparison. We were unable to do a more detailed comparison of nest survival between 1973-1974 and 2009-2010 because of the limitations in the amount and summaries of data from the earlier survey period. We recognize that apparent nest survival usually differs significantly from actual nest survival, and that ideally we would use a logistic exposure model or other approach that evaluates nest survival during the period under which nests are observed for all analyses (Shaffer 2004). However, as our methods were the same as those used by Nuechterlein (1975), it is reasonable to assume that error in detecting nests was similar between 1973-1974 and 2009-2010, so we believe that the comparison between apparent nest survival between these decades is meaningful. Wherever possible, we used the logistic exposure approach for our analyses. We excluded some nests from this analysis (accidentally broken shells, malformed eggs, nests becoming inaccessible due to seasonal water level drops, and carp destruction of nests), because those nest fates were unique to either 1973-1974 or 2009-2010. We also omitted effects of researcher disturbance from the test, because disturbance effects were minimal in all four years and were lower in 2009-2010 than 1973-1974 (1973-1974: $3.3 \%$; 2009: $1.2 \% ; 2010: 0.5 \%)$. The lower disturbance in 2009-2010 may be due to wading researchers spending less time checking nests and being less visible in the dense cattails than the kayaking researchers of 1973-1974 checking nests in sparse bulrush.

For our geo-referenced nests, we assessed effects of habitat structure on nest survival in 2009-2010 using logistic exposure modeling (PROC NLMIXED, SAS Institute, Inc. 2011) (Dinsmore et al. 2002; Shaffer 2004). This allowed us to determine how probability of nest survival was affected by year (2009 or 2010), date of nest initiation, distance of each nest to the open- water edge, fetch and whether or not nests were on the windward or leeward side of their nesting island. We used generalized linear models (PROC GENMOD, SAS Institute, Inc. 2011) to determine whether nest survival differed between sampled nests in the two largest 2009 colonies. There was no significant difference between the two largest 2009 colonies $\left(\chi_{1}^{2}=0.02\right.$, $P>0.1, n=196)$; thus, we omitted the colony variable from the final model. Both initial and later nests were used for this analysis.

We used both a linear and a quadratic function to determine if the effect of nest initiation date (26 May10 August) on nest survival was nonlinear. We assessed seasonal effects using Julian date as a variable. We minimized collinearity between the linear and quadratic term in our models by centering Julian nest initiation dates (Quinn and Keough 2002). We expressed nests on the leeward $(n=166)$ or windward $(n=133)$ side of the islands binomially (leeward $=0$, windward $=1$ ).

We transformed effect sizes and $90 \%$ confidence limits by using Euler's $e^{(\beta)}$ to calculate odds ratios for effect sizes, which are interpreted more easily than $\beta$ values. For example, an odds ratio of 0.4 for fetch of open water would indicate that the odds of a nest being successful are $60 \%$ less likely for every increase of one unit change $(100 \mathrm{~m})$ in fetch of open water $(-1 *(1-$ odds ratio)*100). An odds ratio of 1.4 would indicate that the odds of a nest being successful are $40 \%$ more likely for every increase of one unit change $(100 \mathrm{~m})$ in fetch of open water $(-1 *(1$-odds ratio $) * 100)$.

\section{RESUlts}

\section{Nest Colony Characteristics}

Locations and sizes of colonies in 20092010 varied annually (1-927 nests with eggs per colony; mean $\pm \mathrm{SD}=161 \pm 221$ ), with the largest colonies sampled in 2009-2010 (Blackfox North Island = 239 nests; Gibby's Island $2009=264$ nests; Gibby's Island 2010 $=297$ nests; Sioux Point $=284$ nests) occurring on smaller islands than the largest colony in 1974 (Division Bay South = 261 nests) (Table 1). In 1974, the largest nesting island (Division Bay South) covered $\sim 13,000 \mathrm{~m}^{2}$ (Nuechterlein 1975), 464\% more area than the Blackfox North Island colony in 2009 $\left(2,304 \mathrm{~m}^{2}\right)$, and $764-823 \%$ more area than the southern portion of Gibby's Island during $2009\left(1,505 \mathrm{~m}^{2}\right)$ and $2010\left(1,408 \mathrm{~m}^{2}\right)$. Most colonies were protected from the prevailing northwest winds by being situated on islands that were near northern shorelines or within small sheltered bays, as they were in 1973-1974 (Nuechterlein 1975). 
Table 1. Numbers of nests in the largest colonies of Western Grebes that initiated clutches in one of three periods from June through August, and mean distances (with 95\% confidence intervals) for those nests to the open-water edge $(\mathrm{m})$ within the largest 1974 colony (the only 1973-1974 colony with such data) (Nuechterlein 1975), and the southern portion of Gibby's and Blackfox North Islands at Delta Marsh, Manitoba, during 2009 and 2010. No distance data were collected in 1973 .

\begin{tabular}{|c|c|c|c|c|}
\hline Colony & Year & Initiation Dates & Nests & Distance \\
\hline \multirow[t]{3}{*}{ Division Bay South } & 1974 & 1 June-17 June & 75 & $20.6(18.7,22.5)$ \\
\hline & & 18 June-5 July & 122 & $21.2(19.6,22.8)$ \\
\hline & & 6 July-10 Aug & 64 & $18.3(15.9,20.7)$ \\
\hline \multirow[t]{3}{*}{ Blackfox North Island } & 2009 & 1 June-17 June & 72 & $12.7(11.9,13.5)$ \\
\hline & & 18 June-5 July & 42 & $10.0(8.7,11.3)$ \\
\hline & & 6 July-10 Aug & 29 & $8.6(7.4,9.8)$ \\
\hline \multirow[t]{3}{*}{ Gibby's Island } & 2009 & 1 June-17 June & 25 & $9.8(8.3,11.3)$ \\
\hline & & 18 June-5 July & 28 & $6.7(5.8,7.6)$ \\
\hline & & 6 July-10 Aug & 0 & NA \\
\hline \multirow[t]{3}{*}{ Gibby's Island } & 2010 & 26 May-17 June & 68 & $3.4(3.1,3.7)$ \\
\hline & & 18 June-5 July & 15 & $3.5(3.0,4.0)$ \\
\hline & & 6 July-21 July & 19 & $5.0(4.2,5.8)$ \\
\hline
\end{tabular}

The dominant plant species serving as a nest substrate changed between 19731974 and 2009-2010. In 1973-1974, Western Grebe nests were established predominantly in bulrushes during a low-water year (1973) and predominantly in Phragmites during a high-water year (1974) (Nuechterlein 1975). In contrast, in 2009 and 2010 Western Grebe nests were located primarily in mono-dominant stands of cattail (Typha x glauca) $(100 \%$ of nests in 2009, 98.7\% of nests in 2010), except for an 18-nest colony in 2010 that occurred in emergent hardstem bulrush (Scirpus lacustris spp. glaucus). Nests within cattail islands in deep water were built of cattail stems piled on top of clumps of cattail rhizomes, while nests in shallower areas were constructed of cattail stems piled on the marsh bottom. The 18 nests situated in the relatively deeper waters of a stand of emergent bulrush were built from piled floating bulrush stems.

In the largest colonies of both 2009 and 2010 , the mean distance to the open-water edge was smaller than distances documented for the largest colony (Division Bay South) during the high water year of 1974 (Table 1). Distances of nests to the open-water edge were not available for the low water year of 1973. Initial nests were located primarily near the center of islands, with later nesting efforts radiating outward due to gradu- ally decreasing water levels and increasingly dense cattail stands. As the 2009 nesting season advanced, mean distances to open-water edge decreased (Table 1). Selected nest sites shifted to the periphery of the islands, increasing nest exposure to wave action and contributing to nesting losses. In 2010, low water conditions early in the nesting season exposed dead cattail litter and impenetrable stands of cattails at the centers of nesting islands, causing Western Grebes to nest near the open-water edge. Confidence intervals indicated that mean distance of nests to the open-water edge declined from 2009 to 2010, but did not change as the 2010 nesting season advanced (Table 1).

In 2010, the mean water depth of freshly initiated nests situated in stands of cattail was $24.8 \mathrm{~cm}(\mathrm{SD}=11.2, \min =3.4, \max =$ $45.8, n=134)$. The mean water depth below nests situated in bulrush was $53.4 \mathrm{~cm}$ (SD $=5.4, \min =43.6, \max =63.2, n=14)$. In 1973-1974, mean water depth below nests was $41 \mathrm{~cm}(n=315)$, and $99 \%$ of all nests had depths greater than $25 \mathrm{~cm}$ (Nuechterlein 1975).

Non-overlapping confidence intervals suggest that mean monthly clutch sizes of Western Grebes in 2009-2010 (May: mean \pm $\mathrm{SD}=4.2 \pm 1.2, n=108$; June: $3.5 \pm 0.9, n$ = 620; July: $2.9 \pm 0.9, n=121$ ) were greater than mean monthly clutch sizes in the 1970 s 
(May: mean $\pm \mathrm{SD}=3.7 \pm 0.8, n=122$; June: $3.1 \pm 0.9, n=80$; July: $2.2 \pm 0.5, n=45$; Storer and Nuechterlein 1992).

\section{Weather Effects}

We found no significant difference in mean maximum daily wind speeds from 18 May to 31 July between 1973 and 1974 $\left(t_{149 \text { (Welch's paired 2-tailed) }}: P=0.48\right), 1973$ and 2010 $(P=1.00)$, and 1974 and $2010(P=0.43$; Table 2$)$. Mean maximum daily wind speeds were less in 2009 than $1973\left(t_{118}=3.065, P\right.$ $=0.003), 2009$ than $1974\left(t_{140}=2.873, P=\right.$ $0.005)$ and 2009 than $2010\left(t_{133}=3.528, P\right.$ $<0.001$; Table 2). Numbers of high wind events in the $>30 \mathrm{kmph}$ and $>50 \mathrm{kmph}$ categories of high wind speeds between 1973 and 1974, 1973 and 2010, and 1974 and 2010 were not different $(P>0.05)$. Numbers of high wind speed events in the $>30 \mathrm{kmph}$ and $>50 \mathrm{kmph}$ categories were less in 2009 than $1973\left(\chi^{2}=8.71, P<0.01, n=51\right), 1974$ $\left(\chi_{1}^{2}=11.92, P<0.01, n=51\right)$, and $2010\left(\chi_{1}^{2}=\right.$ 9.28, $P<0$.001, $n=51$; Table 2$)$.

\section{Nest Survival}

Apparent survival of initial nests was $84 \%$ ( $n=181)$ in the two largest colonies during the high water year of $1974,49 \% \quad(n=211)$ in the high water year of 2009 and $43 \%$ ( $n$ $=445$ ) in the low water year of 2010. Apparent nest survival was greater in 1974 than in $2009\left(\chi^{2}{ }_{1}=55.18, P<0.001\right)$ and $2010\left(\chi^{2}{ }_{1}\right.$ $=345.53, P<0.001)$. Apparent nest survival in the low water year of 1973 was $46 \%$ ( $n=$ $195)$ and did not differ from that in the high water year of $2009\left(\chi_{1}^{2}=2.18, P>0.10\right)$, but was greater than apparent nest survival in 2010 , another low water year $\left(\chi_{1}^{2}=211.85\right.$, $P<0.001)$.
The percentage of Western Grebe nests lost during 1973-1974 was lower than in 2009-2010 (Table 3) $\left(\chi_{1}^{2}=4,571.3, P<0.001\right.$, $n=830)$. The highest percentage of nesting losses for both study periods was caused by wave action during storms, but the percentage of nest failures caused by wave destruction increased from 1973-1974 to 2009-2010 (Table 3). Destruction of initial nests by spawning carp was the second-greatest cause of nest failure, but this occurred solely in 2009 ( $7.1 \%$ of nest failures) (Table 3 ) and in only one colony. Rates of nest abandonment were lower $\left(\chi_{1}^{2}=7.88, P<0.01, n=1,714\right)$ in 2009 and 2010 than in 1973 and 1974 (Table 3 ). Other sources of nest failure were less important, although there was evidence of depredation of eggs by Forster's Terns and nesting adults by mink (Neovison vison), river otters (Lontra canadensis), and Great Horned Owls (Bubo virginianus). Several carcasses in 2009 and 2010 were decapitated, which is characteristic of mink or Great Horned Owl depredation (Olmsted 1950; Nuechterlein $e t$ al. 2003). River otter scat was found containing adult Western Grebe body feathers.

\section{Chick-Adult Ratios}

As in 1973-1974 (Nuechterlein 1975), the chick-adult ratio was lower in the low-water year (2010) compared with the high-water year (2009) (Table 4). The 2009 chick-adult ratio was $38.6 \%$ less than the other highwater year, 1974, and between the low-water years, 1973 and 2010, there was a decrease of $29.1 \%$ (Table 4 ). In 2009, the chick-adult ratio was slightly higher $(0.68)$ on Lake Manitoba than in the marsh (0.39 and 0.55$)$; neither chicks nor adults were detected on Lake Manitoba in 2010. In contrast, numbers of adult Western Grebes detected increased

Table 2. Number of days between 18 May and 31 July with high wind events and intensity of wind events used to calculate mean daily maximum wind speeds at Delta Marsh, Manitoba, during 1973, 1974, 2009 and 2010.

\begin{tabular}{lcccc}
\hline \hline & 1973 & 1974 & 2009 & 2010 \\
\hline \# Days $\leq 31 \mathrm{kmph}$ & 24 & 22 & 30 & 19 \\
\# Days > 30 kmph & 51 & 53 & 45 & 56 \\
\# Days > 50 kmph & 18 & 21 & 6 & 17 \\
\# Days > 70 kmph & 6 & 2 & 0 & 3 \\
Mean daily wind speed (kmph) & 39.6 & 37.3 & 30.1 & 39.6 \\
\hline
\end{tabular}


Table 3. Total number and percentages of nest failures for different probable causes within four major Western Grebe colonies at Delta Marsh, Manitoba, in 1973-1974 (Nuechterlein 1975) and within Gibby's and Blackfox North Islands at Delta Marsh, Manitoba, in 2009-2010. Data from 1973-1974 were combined by Nuechterlein (1975) and were not available separately.

\begin{tabular}{|c|c|c|c|c|c|c|c|}
\hline \multirow[b]{2}{*}{ Probable Cause } & \multirow[b]{2}{*}{ Evidence } & \multicolumn{2}{|c|}{$1973-1974$} & \multicolumn{2}{|l|}{2009} & \multicolumn{2}{|l|}{2010} \\
\hline & & $\begin{array}{c}\text { Total } \\
\text { Number }\end{array}$ & $\%$ & $\begin{array}{c}\text { Total } \\
\text { Number }\end{array}$ & $\%$ & $\begin{array}{c}\text { Total } \\
\text { Number }\end{array}$ & $\%$ \\
\hline Accidentally broken eggs & Cracked or smashed egg shells & 4 & 0.8 & 0 & NA & 1 & 0.1 \\
\hline Abnormal eggs & Malformed eggs & 0 & 0 & 2 & 0.3 & 0 & 0 \\
\hline \multicolumn{8}{|l|}{ Predation } \\
\hline Mammalian & Portions of carcass on or near nest & 7 & 1.4 & 2 & 0.3 & 4 & 0.4 \\
\hline Avian & Pecked eggs & 24 & 4.7 & 2 & 0.3 & 0 & 0 \\
\hline Carp destruction & Carp observed destroying nests & 0 & 0 & 41 & 7.1 & 0 & 0 \\
\hline \multicolumn{8}{|l|}{ Abandonment } \\
\hline Human Hddisturbance & Eggs cold, marked, or not rotated & 17 & 3.3 & 7 & 1.2 & 6 & 0.5 \\
\hline Water level & Absence of water around nest & 0 & 0 & 15 & 2.6 & 1 & 0.1 \\
\hline Wave destruction & Nest/eggs missing or washed out & 111 & 21.5 & 284 & 49.1 & 538 & 47.4 \\
\hline \multicolumn{2}{|c|}{ Total losses of checked nests* } & 163 & 31.6 & 353 & 61.1 & 550 & 48.4 \\
\hline
\end{tabular}

$*_{n}=516$ (1973-1974), $n=578$ (2009), $n=1136$ (2010).

by approximately $30 \%$ from the $1973-1974$ study period to 2010 (Table 4).

\section{Effects of Habitat Structure on Nest Survival}

We analyzed effects of habitat structure on survival of 197 nests (118 successful nests) from 2009, and 102 nests (48 successful nests) from 2010. These nests were initiated from 26 May-9 August (median = 13 June, interquartile range $=23$ days). Nest distance to the nearest open-water edge ranged from $0.5-21.4 \mathrm{~m}$ (mean $\pm \mathrm{SD}=8.1 \pm 4.8)$. Fetch of open water ranged from 121-2,879 $\mathrm{m}$ (mean $\pm \mathrm{SD}=525.1 \pm 445.3$ ). Odds of nest survival increased by $12.47 \%$ with each $1-\mathrm{m}$ increase from the open-water edge to a nest (Table 5). Odds of nest survival declined from 2009 to 2010 (Table 4) and peaked approximately 15 June (Table 5, Fig. 2). There was a small but statistically significant effect of fetch; for every increase of $100 \mathrm{~m}$ in fetch of open water, the odds of nest survival decreased by $0.06 \%$ (Table 5). Being on the leeward or windward side of an island did not affect survival of nests (Table 5).

\section{Discussion}

Composition of nests and nesting habitat of Western Grebes at Delta Marsh changed between 1973-1974 and 2009-2010, from predominantly bulrushes to almost entirely hybrid cattails. This change was concomitant with a decrease in distances from nests to

Table 4. Apparent nest survival (\%), population estimates from brood surveys, and chick-adult ratios of Western Grebes from August brood surveys at Delta Marsh, Manitoba, during 1973, 1974, 2009, and 2010. Brood surveys all took place in Delta Marsh except for surveys in Lake Manitoba on 6 August 2009 and 6 August 2010. Apparent percent survival is the percent of the nests found that produced at least one chick.

\begin{tabular}{|c|c|c|c|c|c|c|c|c|}
\hline Year & Water Level & Nests & $\begin{array}{l}\text { Successful } \\
\text { Nests }\end{array}$ & $\begin{array}{c}\text { Apparent } \\
\text { Survival (\%) }\end{array}$ & $\begin{array}{c}\text { Brood } \\
\text { Survey Date }\end{array}$ & Adults & Chicks & $\begin{array}{c}\text { Chick-Adult } \\
\text { Ratio }\end{array}$ \\
\hline 1973 & Low & 195 & 90 & 46 & 1-3 August & 483 & 267 & 0.55 \\
\hline 1974 & High & 181 & 152 & 84 & 5 August & 488 & 429 & 0.88 \\
\hline \multirow[t]{3}{*}{2009} & High & 211 & 104 & 49 & 5 August & 298 & 163 & 0.55 \\
\hline & & & & & 6 August & 197 & 133 & 0.68 \\
\hline & & & & & Both days & 495 & 296 & 0.60 \\
\hline \multirow[t]{2}{*}{2010} & Low & 445 & 190 & 43 & 5 August & 632 & 251 & 0.39 \\
\hline & & & & & 6 August & 0 & 0 & - \\
\hline
\end{tabular}


Table 5. Influence of timing and location of nests on odds ratios for predicting probability of success for Western Grebe nests at Delta Marsh, Manitoba, 2009-2010.

\begin{tabular}{lccr}
\hline \hline Parameter & $\beta \pm \mathrm{SE}$ & Odds Ratio $(95 \% \mathrm{CI})$ & $P$ \\
\hline Intercept & $3.735 \pm 0.323$ & $41.888(24.584,71.346)$ & $<0.001$ \\
Year & $-0.475 \pm 0.264$ & $0.622(0.403,0.960)$ & 0.072 \\
Day (adjusted) & $0.004 \pm 0.008$ & $1.004(0.991,1.017)$ & 0.616 \\
Day (adjusted) & & $0.988(0.998,0.999)$ & 0.002 \\
Distance to edge $(\mathrm{m})$ & $-0.012 \pm 0.000$ & $1.125(1.068,1.184)$ & $<0.001$ \\
Fetch $(100 \mathrm{~m})$ & $0.118 \pm 0.031$ & $0.999(0.999,1.000)$ & 0.005 \\
Leeward $(=0)$ or windward $(=1)$ & $-0.001 \pm 0.000$ & $0.862(0.618,1.202)$ & 0.461 \\
\hline
\end{tabular}

open-water edge, probably in part because the nesting islands sampled in 2009 were much smaller than the nesting island sampled in 1974 (Nuechterlein 1975; equivalent measurements were not made in 1973), and in part because of the proliferation of hybrid cattails in dense mono-dominant stands (Boers 2006). The main consequences may be: 1) lower apparent nest survival in 20092010 compared with 1973-1974 after controlling for water level; 2) an increase in the rate of wave-caused nesting losses in 20092010; and 3) lower apparent nest survival in years with low water levels $(1973,2010)$ than in years with high water levels (1974, 2009). Apparent nest survival may exceed actual nest survival (Johnson 1979), but it was not possible to calculate actual nest survival using the data available for 1973 and 1974; our comparison of nest survival over time should, therefore, be interpreted with caution. Wave action causing nest disintegration was the single most important source of nesting failure in all periods and has been implicated as a significant source of nest failure for other over-water nesting waterbirds in Delta Marsh (McNicholl 1982; Van Damme 2004, 2006; Summers et al. 2009).

We attributed a key reason for the increase in nest destruction by waves to a change in nesting habitat for Western Grebes at Delta Marsh. First, wind strength did not increase between 1973-1974 and 2009-2010; thus, changes in wind cannot explain increasing nest losses to wave action. Second, decreases in submerged vegetation like bulrushes (Goldsborough and Wrubleski 2001) reduce the attenuation of wave energy at nests.

The replacement of bulrush stands with hybrid cattails also resulted in Western Grebes nesting closer to open water. As summer advances, hybrid cattail islands became very dense and impenetrable to nesting pairs seeking sheltered nest sites, because Western

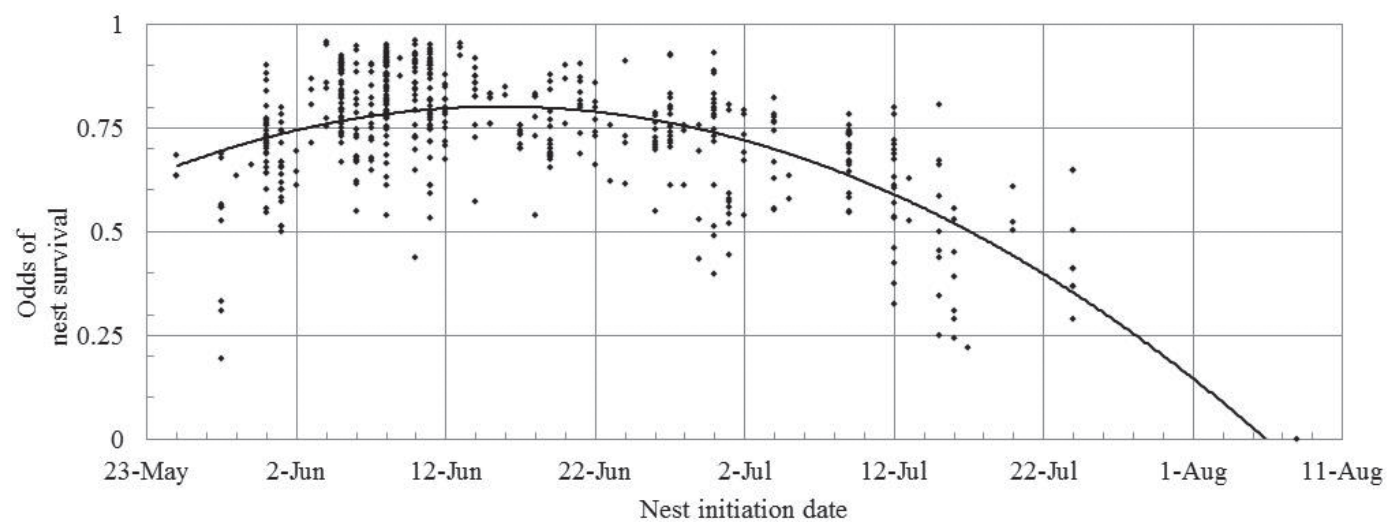

Figure 2. Odds of Western Grebe daily nest survival $(n=299)$ relative to time of season (nest initiation date) in 2009-2010 at Delta Marsh, Manitoba, after controlling for effects of year, fetch, nest distance to nearest open-water edge, and nest position with respect to prevailing winds (leeward or windward side of island). 
Grebes have their feet set at the posterior end of the body, making them poorly adapted to movement through dense vegetation (Storer and Nuechterlein 1992). In 2010, low water levels further limited the distance in which nesting pairs could penetrate the island to $<6 \mathrm{~m}$ from the open-water edge. This may also explain, in part, why nest survival was higher in high-water than in low-water years. In years with high water levels, nesting Western Grebes can penetrate the inner areas of vegetated islands and benefit from the protection a vegetated buffer provides to the nest platform (Nuechterlein 1975; Allen et al. 2008). In years with low water levels, Western Grebes were restricted to nesting in island peripheries (Nuechterlein 1975; Storer and Nuechterlein 1992). The probability of nest survival may have been highest mid-season because early cattail growth was too sparse to buffer nests from waves, while late-season cattail growth made central areas of nesting islands inaccessible to Western Grebes. Thus, marsh water depth is critical in influencing nesting outcomes because it influences nest distance from open water, and, in the long term, vegetation species composition.

We recognize that nest survival might have been driven by factors other than vegetation, a fact that we cannot test with the data available to us. Although the location of nests on the windward side of nesting colonies did not strongly affect nest survival in this study, this may result from winds coming from more than one direction during the study, or because our measure of leeward and windward sides were relatively coarse. As nests were closer to open-water edge in 2009 and 2010 than during the 1973-1974 study period, even moderate or occasional winds and waves from any direction may have destroyed peripheral nests. However, cumulatively, our evidence suggests that smaller nesting islands and an overall change in vegetation substrate interacted with water depth and wave action to reduce nest survival in 2009-2010 compared with 1973-1974.

Incidental nest losses in 2009-2010 due to carp were not documented at Delta Marsh in 1973-1974, although spawning carp were ob- served tearing American Coot (Fulica americana) and Forster's Tern nests apart and smashing one Forster's Tern egg in 1968 and 1969 (McNicholl 1982). In one incident, violently thrashing carp caused the loss of 41 nests on 11 June 2009. If carp populations increase, nest losses may increase for overwater-nesting birds like Western Grebes, both in Delta Marsh and other freshwater habitats that sustain populations of invasive carp (Zambrano et al. 2006; Badiou and Goldsborough 2010). Furthermore, because carp commonly spawn in shallow waters (20$50 \mathrm{~cm}$; Crivelli 1983) within macrophyte stands (Balon 1995; Chow-Fraser 1999), nests are more likely to be destroyed by carp in shallower waters or if wetland water levels are lower.

Our results suggest that declines in chickadult ratios at Delta Marsh from 1973-1974 to 2009-2010, and between years with high and low water levels, may have been driven by the concurrent declines in apparent nest survival that we observed, although our methods did not allow us to determine causes of declines in chick-adult ratios over time. Declining chick-adult ratios were not as a result of reduced clutch sizes, because mean clutch size per nest increased from 1973-1974 to 20092010. However, declines in chick-adult ratios occurred concurrently with increases in adult bird counts on brood surveys from 1973-1974 to 2009-2010; the latter may reflect increases in Western Grebe abundance within the Prairie Pothole Region from 1966 to 2009 (Sauer et al. 2011) or, alternatively, threats of habitat loss and degradation elsewhere in the breeding range could also cause population shifts from other areas to Delta Marsh (International Union for the Conservation of Nature/Species Survival Commission 1997). Furthermore, the increase in numbers of observed nests at Delta Marsh from 1973-1974 to 2009-2010 included re-nesting efforts after previous nest failures. Thus, counts of nests might not indicate the population-wide number of breeding pairs (Kushlan 1992) or habitat quality for Western Grebes (Van Horne 1983), and the apparent declines in productivity that we demonstrated should still be of management concern. 
Stabilization of water levels in Delta Marsh and Lake Manitoba has in part contributed to changes in the plant community in Delta Marsh. This has in turn led to a reduction in wave attenuation near nests and a reduction in Western Grebe nest distances to open-water edge, leading to greater rates of nest failure due to wave action since 19731974. Thus, management strategies that replace cattails with native wetland plants like bulrushes should reduce rates of wave destruction of nests. Although a low-water year would be detrimental to nesting Western Grebes for a single season, controlled drawdowns expose the marsh bottom and permit seed germination. Regrowth of native wetland vegetation such as bulrushes would strongly benefit the marsh in the long term (Squires and van der Valk 1992).

Reducing carp abundance through the implementation of carp screens should be beneficial for Western Grebes and other birds that nest in emergent vegetation at Delta Marsh, like Red-necked Grebes ( $P$. grisegena) (Nuechterlein et al. 2003) and Forster's Terns (McNicholl 2003a). Decreasing the abundance of carp should assist in the reestablishment of submerged and emergent macrophytes (Hnatiuk 2006; Miller and Crowl 2006), which should increase nesting habitat for Western Grebes and increase the frictional forces acting upon waves (Denny 1988; Hall et al. 1998). Reducing carp abundance should also reduce the number of nests that are incidentally destroyed by carp, though this source of nest failure may be a rare event.

The showy, complex open-water mating displays of Western Grebes (Storer and Nuechterlein 1992) make it a charismatic species that can be used to promote ecotourism, education, and conservation of wetlands. Western Grebes and other wetland birds are also acutely sensitive to disturbance (Storer and Nuechterlein 1992) and, therefore, are useful indicators of ecosystem function, health, and change (Caro and O'Doherty 1998). Therefore, potential adverse impacts on Western Grebe nest survival should be considered when managing Delta Marsh and other wetlands with similar conditions (e.g., carp, water level stabilization, Typha $\times$ glauca proliferation).

ACKNOWLEDGMENTS

This study was approved by the animal care committee at the University of Manitoba (Protocol \# F09-007) and federal scientific permits were issued on behalf of the Canadian Wildlife Service (09-MB-SC004). Funding for this study was provided by the Sustainable Development and Innovation Fund (Manitoba Conservation) and the Delta Marsh Field Station Scholarship. In-kind support was provided by Ducks Unlimited Canada and the Delta Marsh Field Station of the University of Manitoba. Advice was provided by Ron Bazin, Dr. Gordon Goldsborough, Dr. Gary Nuechterlein, Dr. Dale Wrubleski, Dr. Spencer Sealy, Ken DeSmet and four reviewers. Technical support was provided by Garth Ball and Sones Keobouas. Access to private land was provided by Delta Waterfowl.

\section{Literature Cited}

Allen, J. A., G. L. Nuechterlein and D. Buitron. 2008. Weathering the storm: how wind and waves impact Western Grebe nest placement and success. Waterbirds 31: 402-410.

Badiou, P. H. J. and L. G. Goldsborough. 2010. Ecological impacts of an exotic benthivorous fish in large experimental wetlands, Delta Marsh, Canada. Wetlands 30: 657-667.

Balon, E. K. 1995. The common carp, Cyprinus carpio: its wild origin, domestication in aquaculture and selection as colored nishigoi. Guelph Ichthyology Reviews 3: 1-54.

Beyersbergen, G. W., N. D. Niemuth and M. R. Norton. 2004. Northern Prairie and Parkland waterbird conservation plan. A plan associated with the Waterbird Conservation for the Americas Initiative. U.S. Fish and Wildlife Service, Prairie Pothole Joint Venture, Denver, Colorado.

Boers, A. M. 2006. The effects of stabilized water levels on invasion by hybrid cattail (Typha $\mathrm{x}$ glauca). Ph.D. Dissertation, University of Wisconsin, Madison.

Boonstra, T. A. 2006. Effects of maternal investments on egg metabolic rates, hatching synchrony and offspring performance in Canada Geese (Branta canadensis maxi$m a)$. M.S. Thesis, North Dakota State University, Fargo.

Breukelaar, A. W., E. H. R. R. Lammens and J. G. P. Klein Breteler. 1994. Effects of benthivorous bream (Ambramis brama) and carp (Cyprinus carpio) on sediment resuspension and concentration of nutrients and chlorophyll-a. Freshwater Biology 32: 113-121.

Caro, T. M. and G. O'Doherty. 1998. On the use of surrogate species in conservation biology. Conservation Biology 13: 805-814.

Chow-Fraser, P. 1998. A conceptual ecological model to aid restoration of Cootes Paradise Marsh, a degraded coastal wetland of Lake Ontario, Canada. Wetlands Ecology and Management 6: 46-57. 
Chow-Fraser, P. 1999. Seasonal, interannual and spatial variability in the concentrations of total suspended solids in a degraded coastal wetland of Lake Ontario. Journal of Great Lakes Research 25: 799-813.

Crivelli, A. J. 1983. The destruction of aquatic vegetation by carp. Hydrobiologia 106: 37-41.

Denny, M. 1988. Biology and the mechanics of the waveswept environment. Princeton University Press, Princeton, New Jersey.

Dinsmore, S. T., G. C. White and F. L. Knopf. 2002. Advanced techniques for modeling nest survival. Ecology 83: 3476-3488.

Environment Canada. 2011. Water Survey Canada, hydrometric data: Lake Manitoba near Westbourne (05LL012). Environment Canada, Ottawa, Ontario. http://www.wsc.ec.gc.ca/, accessed 6 January 2011.

Environment Canada. 2012. National climate data and information archive: Portage Southport Airport Manitoba. Environment Canada, Ottawa, Ontario. http://climate.weatheroffice.gc.ca/, accessed 6 January 2011.

Environmental Systems Research Institute (ESRI). 2002. ArcGIS v. 10. ESRI, Redlands, California.

Evelsizer, V. D. and A. M. Turner. 2006. Species-specific responses of aquatic macrophytes to fish exclusion in a prairie marsh: a manipulative experiment. Wetlands 26: 430-437.

Goldsborough, L. G. and D. A. Wrubleski. 2001. The decline of Delta Marsh, an internationally significant wetland in south-central Manitoba. Pages 202-221 in Proceedings of the Sixth Prairie Conservation and Endangered Species Conference (D. Blouin, Ed.). Manitoba Habitat Heritage Corporation, Winnipeg, Manitoba.

Greenwood, R. J. and A. B. Sargeant. 1995. Effect of a commonly-used nest marker on nest success of ducks in Prairie Canada. Canadian Field-Naturalist 109: 437-440.

Hall, K. R., P. Tschirky and D. J. Turcke. 1998. Coastal wetland stability and shore protection. Journal of Coastal Research Special Issue 26: 96-101.

Havens, K. E. 1991. Fish-induced sediment resuspension: effects on phytoplankton biomass and community structure in a shallow hypereutrophic lake. Journal of Plankton Research 13: 1163-1176.

Hnatiuk, S. D. 2006. Experimental manipulation of ponds to determine the impact of common carp (Cyprinus carpio L.) in Delta Marsh, Manitoba: effects on water quality, algae and submersed vegetation. M.S. Thesis, University of Manitoba, Winnipeg.

Hochbaum, P. W. 1971. The Delta Marsh. Unpublished report to the Manitoba Department of Mines, Resources and Environmental Management, Winnipeg, Manitoba.

International Union for the Conservation of Nature/ Species Survival Commission (IUCN/SSC). 1997. Grebes: status survey and conservation action plan. IUCN/SSC Grebe Specialist Group, International Union for the Conservation of Nature, Gland, Switzerland. http://data.iucn.org/dbtw-wpd/edocs/1997-058.pdf, accessed 24 April 2009.
Johnson, D. H. 1979. Estimating nest success: the Mayfield method and an alternative. Auk 96: 651-661.

Keddy, P. A. and A. A. Reznicek. 1986. Great Lakes vegetation dynamics: the role of fluctuating water levels and buried seeds. Journal of Great Lakes Research 12: 25-36.

Koonz, W. and P. W. Rakowski. 1985. Status of colonial waterbirds nesting in southern Manitoba. Canadian Field-Naturalist 99: 19-25.

Kuehn, M. M. and B. N. White. 1999. Morphological analysis of genetically identified cattails Typha latifolia, Typha angustifolia and Typha x glauca. Canadian Journal of Botany 77: 906-912.

Kushlan, J. A. 1992. Population biology and conservation of colonial wading birds. Colonial Waterbirds 15: 1-7.

Larkin, D. J., M. J. Freyman, S. C. Lishawa, P. Geddes and N. C. Tuchman. 2012. Mechanisms of dominance by the invasive hybrid cattail Typha $\mathrm{x}$ glauca. Biological Invasions 14: 65-77.

Lindvall, M. L. and J. B. Low.1982. Nesting ecology and reproduction of Western Grebes at Bear River Migratory Bird Refuge, Utah. Condor 84: 66-70.

Lokemoen, J. T. and R. O. Woodward. 1992. Nesting waterfowl and water birds on natural islands in the Dakotas and Montana. Wildlife Society Bulletin 20: 163-171.

McNicholl, M. L. 1982. Factors affecting nest survival of Forster's Terns at Delta Marsh, Manitoba. Colonial Waterbirds 5: 32-38.

McNicholl, M. L. 2003a. Forster's Tern Sterne de Forster Sterna forsteri Nuttall. Page 213 in The Birds of Manitoba (P. Taylor, Ed.). Manitoba Naturalists Society, Winnipeg, Manitoba.

McNicholl, M. L. 2003b. History of ornithology in Canada's keystone province. Pages 10-27 in The Birds of Manitoba (P. Taylor, Ed.). Manitoba Naturalists Society, Winnipeg, Manitoba.

Miller, S. A. and T. A. Crowl. 2006. Effects of common carp (Cyprinus carpio) on macrophytes and invertebrate communities in a shallow lake. Freshwater Biology 51: 85-94.

Nero, R. W. 1958. Dry-land nest-site of a Western Grebe colony. Auk 75: 347-349.

Nuechterlein, G. L. 1975. Nesting ecology of Western Grebes on the Delta Marsh. M.S. Thesis, Colorado State University, Fort Collins.

Nuechterlein, G. L. 2003. Western Grebe Grèbe Élégant Aechmophorus occidentalis Lawrence. Page 79 in The Birds of Manitoba (P. Taylor, Ed.). Manitoba Naturalists Society, Winnipeg, Manitoba.

Nuechterlein, G. L., D. Buitron, J. L. Sachs and C. R. Hughes. 2003. Red-necked Grebes become semicolonial when prime nesting substrate is available. Condor 105: 80-94.

Olmsted, R. O. 1950. Feeding habits of Great Horned Owls, Bubo virginianus. Auk 67: 515-516.

Quinn, G. P. and M. L. Keough (Eds.). 2002. Experimental design and data analysis for biologists. Cambridge University Press, Cambridge, U.K.

Ramsar Convention. 2009. The annotated Ramsar list. Ramsar Convention, International Union for the Con- 
servation of Nature, Gland, Switzerland. http://www. ramsar.org/cda/en/ramsar-documents-list-anno-listusa/main/ramsar/1-31-218\%5E15774_4000_0_, accessed 7 January 2014.

SAS Institute, Inc. 2011. SAS statistical software v. 9.3. SAS Institute, Inc., Cary, North Carolina.

Sauer, J. R., J. E. Hines, J. E. Fallon, K. L. Pardieck, D. J. Ziolkowski, Jr. and W. A. Link. 2011. The North American Breeding Bird Survey, results and analysis 1966-2009 v.3.23.2011. U. S. Department of the Interior, Geological Survey, Patuxent Wildlife Research Center, Laurel, Maryland. http://www.pwrc.usgs. gov/bbs/, accessed 4 April 2011.

Seabloom, E. W., K. A. Moloney and A. G. van der Valk. 2001. Constraints on the establishment of plants along a fluctuating water-depth gradient. Ecology 82: 2216-2232.

Shaffer, T. L. 2004. A unified approach to analyzing nest success. Auk 121: 526-540.

Shay, J., P. M. J. de Geus and M. R. M. Kapinga. 1999. Changes in vegetation over a 50-year period in the Delta Marsh, Manitoba in response to water levels. Wetlands 19: 423-425.

Squires, L. and A. G. van der Valk. 1992. Water-depth tolerances of the dominant emergent macrophytes of the Delta Marsh, Manitoba. Canadian Journal of Botany 70: 1860-1867.

Storer, R. W. and G. L. Nuechterlein. 1992. Western and Clark's Grebe. No. 26 in The Birds of North America (A. Poole, P. Stettenheim and F. Gill, Eds.). Academy of Natural Sciences, Philadelphia, Pennsylvania; American Ornithologists' Union, Washington, D.C.

Summers, R. W., R. A. Mayor and M. H. Hancock. 2009. Correlates of breeding success of Horned Grebes in Scotland. Waterbirds 32: 265-275.

Van Damme, L. M. 2004. Weather influences parenting behavior among Red-necked Grebes and Western Grebes on Duck Lake, Creston Valley. Wildlife Afield 1: 67-69.

Van Damme, L. M. 2006. Western Grebe parasitism on Red-necked Grebe nests on Duck Lake, Creston Valley. Wildlife Afield 3: 121-125.

Van Horne, B. 1983. Density as a misleading indicator of habitat quality. Journal of Wildlife Management 47: 893-901.

Zambrano, L. E. Martinez-Meyer, M. Naercio and A. T. Peterson. 2006. Invasive potential of common carp (Cyprinus carpio) and Nile tilapia (Oreochromis niloticus) in American freshwater systems. Canadian Journal of Fisheries and Aquatic Sciences 63: 1903-1910. 